\title{
ISCHEMIC PITUITARY APOPLEXY, HYPOPITUITARISM AND DIABETES INSIPIDUS: A TRIAD UNIQUE TO NECROTIZING HYPOPHYSITIS
}

\author{
Miroslav Ćaćić ${ }^{1}$, Jelena Marinković ${ }^{1}$, Ivan Kruljac ${ }^{1}$, Božidar Perić ${ }^{1}$, Vatroslav Čerina ${ }^{2}$, \\ Darko Stipić 2 , Leo Pažanin ${ }^{3}$, Hrvoje Ivan Pećina ${ }^{4}$ and Milan Vrkljan ${ }^{1}$ \\ ${ }^{1}$ Mladen Sekso Department of Endocrinology, Diabetes and Metabolic Diseases, Sestre milosrdnice \\ University Hospital Center, School of Medicine, University of Zagreb, Zagreb, Croatia; \\ ${ }^{2}$ Department of Neurosurgery, Sestre milosrdnice University Hospital Center, Zagreb, Croatia; \\ ${ }^{3}$ Ljudevit Jurak Department of Pathology, Sestre milosrdnice University Hospital Center, Zagreb, Croatia; \\ ${ }^{4}$ Department of Radiology, Sestre milosrdnice University Hospital Center, Zagreb, Croatia
}

SUMMARY - A rare case of necrotizing hypophysitis (NH) in a 52-year-old man presenting with pituitary apoplexy and sterile meningitis is described. This case indicates that the diagnosis of $\mathrm{NH}$ could be made without biopsy, based on concomitant presence of diabetes insipidus, hypopituitarism and radiologic features of ischemic pituitary apoplexy. Conservative management of pituitary apoplexy should be advised in NH. Additionally, this is the first report of a case of sterile meningitis caused by ischemic pituitary apoplexy.

Key words: Stroke; Diabetes insipidus; Hypopituitarism; Hypophysitis; Pituitary apoplexy; Meningitis

\section{Introduction}

Hypophysitis is a rare inflammatory disorder associated with diffuse enlargement and dysfunction of the pituitary gland, with estimated prevalence of $0.88 \%{ }^{1}$. During the preoperative period, it is misdiagnosed as pituitary adenoma in up to $40 \%$ of cases $^{2}$, although these two clinical entities can be readily distinguished based on the absence of diabetes insipidus in patients with adenoma ${ }^{1}$. Several radiologic markers on magnetic resonance imaging (MRI) are indicative of hypophysitis, i.e. pituitary stalk thickening, pituitary enlargement, intense homogeneous post-contrast imbibition in adenohypophysis, and absence of high-intense signal in neurohypophysis on T1-weighted images $^{3}$. Based on histopathologic examination, which

Correspondence to: Ivan Kruljac, MD, Mladen Sekso Department of Endocrinology, Diabetes and Metabolic Diseases, Sestre milosrdnice University Hospital Center, Vinogradska c. 29, HR10000 Zagreb, Croatia

E-mail: ivkruljac@gmail.com

Received April 12, 2016, accepted June 13, 2016 is needed to confirm the diagnosis, primary hypophysitis can be categorized into five groups: lymphocytic, granulomatous, xanthomatous, IgG4 plasmacytic, and necrotizing hypophysitis $(\mathrm{NH})^{2}$. $\mathrm{NH}$ is the rarest type, with only 3 cases reported in the literature so $\operatorname{far}^{4,5}$. Here we present another patient with biopsy-proven $\mathrm{NH}$, and discuss its pathogenesis, clinical presentation and treatment options.

\section{Case Report}

A 52-year-old man was admitted to the hospital with rapidly progressive headache, vomiting and photophobia. His medical history was unremarkable. On admission, he had normal blood pressure, normal heart rate and axillary temperature of $37.5^{\circ} \mathrm{C}$. Physical examination was unremarkable. His complete blood count $(\mathrm{CBC}), \mathrm{C}$-reactive protein (CRP) and electrolyte panel were all normal; slightly low urine specific gravity was noted $(1.003 \mathrm{~g} / \mathrm{L})$. Computed tomography scan showed inhomogeneous intrasellar mass sugges- 

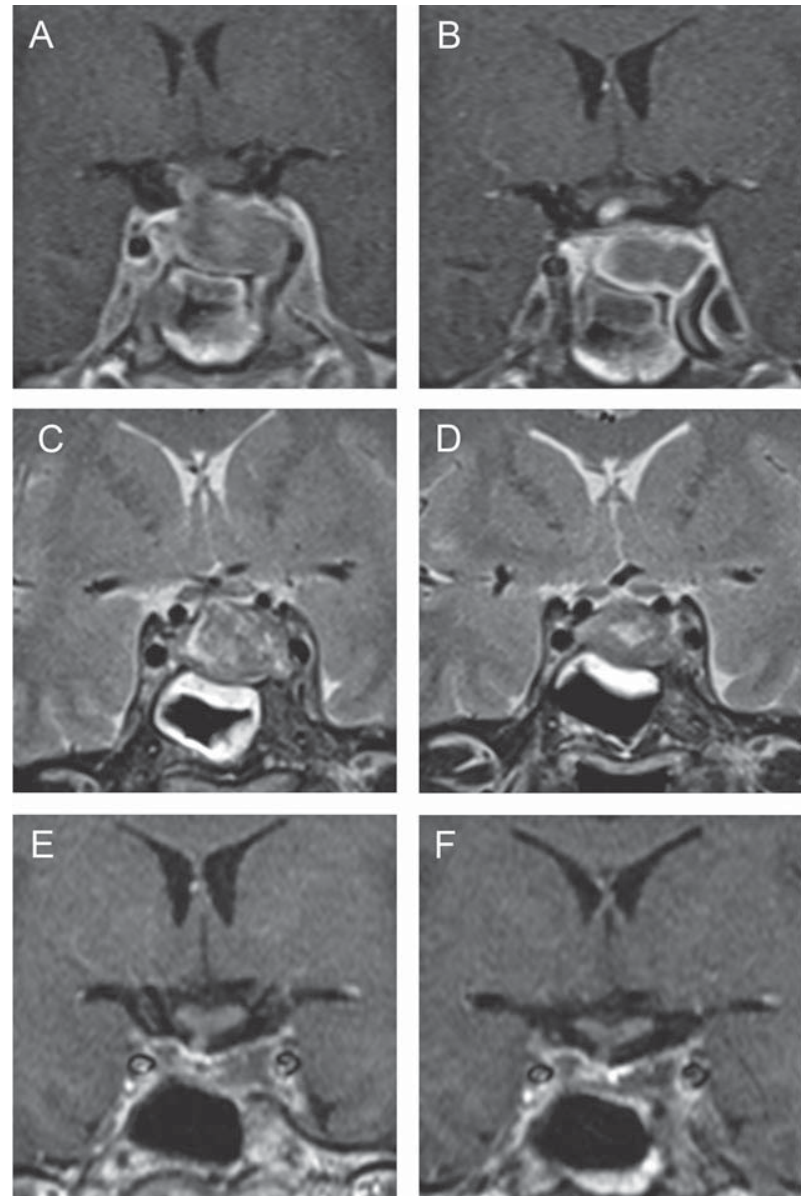

Fig. 1. Magnetic resonance imaging in a patient with necrotizing hypophysitis showing lack of enhancement within enlarged pituitary gland on contrast-enhanced imaging, which is hypointense to isointense to the gray matter on T1-weighted images and thickened pituitary stalk (A); progression of ischemia 12 days after symptom onset with rim enhancement on T1-weighted images (B); thickened sphenoidal sinus mucosa on T2-weighted images (C), and regression of edema twelve days after symptom onset (D); residual necrotic pituitary tissue on contrast-enhanced imaging $4(E)$ and $18(F)$ months after the surgery.

tive of pituitary adenoma. His headache intensified and paresis of the left third cranial nerve developed two days after admission. He became febrile up to 39.8 ${ }^{\circ} \mathrm{C}$, with marked neck stiffness and excessive diuresis (10 L of urine per day). CRP increased to $82 \mathrm{mg} / \mathrm{L}$ but his $\mathrm{CBC}$ remained normal. Analysis of the cerebrospinal fluid (CSF) suggested sterile meningitis (glucose level $4.4 \mathrm{mmol} / \mathrm{L}$, protein concentration $1.0 \mathrm{~g} / \mathrm{L}$ and white blood cell count $46 / \mathrm{mm}^{3}$ ( $90 \%$ of lymphocytes)). MRI performed two days after symptom onset demonstrated diffusely enlarged pituitary gland $(23 \times 15 \times 17$ $\mathrm{mm}$ ), which was slightly hypointense to isointense to the gray matter on T1-weighted images, with thickened pituitary stalk (Fig. 1 A, B). Hypophysitis was suspected, although dynamic contrast-enhanced imaging did not show enhancement within the enlarged pituitary gland. Thickened sphenoid sinus mucosa along with sudden symptom onset suggested pituitary apoplexy. Endocrinologic evaluation revealed adrenal insufficiency (morning serum cortisol of $30 \mathrm{nmol} / \mathrm{L}$ ) and diabetes insipidus (urine osmolality of $106 \mathrm{mOsm} /$ $\mathrm{kg})$. Hydrocortisone and desmopressin replacement therapy was administered. The patient's headache, fever and third cranial nerve palsy resolved spontaneously seven days after the onset. Follow up lumbar puncture confirmed aseptic meningitis (glucose level of $3.3 \mathrm{mmol} / \mathrm{L}$, protein concentration of $1.83 \mathrm{~g} / \mathrm{L}$, and white blood cell count of $420 / \mathrm{mm}^{3}$ (70\% of monocytes)). CSF testing was negative for Mycobacterium tuberculosis, Cryptococcus, and other fungi. Serologic analysis was negative for toxoplasma, Treponema pallidum, tick-borne encephalitis, Epstein-Barr virus, cytomegalovirus, Borrelia burgdorferi and human herpes virus 6. Follow up MRI performed twelve days after symptom onset (Fig. $1 \mathrm{~B}, \mathrm{D}$ ) showed enlarged pituitary gland that was profoundly hypointense to the gray matter on T1-weighted images, with only rim enhancement detected on post-contrast images, a finding suggestive of ischemic necrosis. Thickening of the sphenoid sinus mucosa diminished substantially. Detailed endocrinologic evaluation confirmed adrenal insufficiency (cortisol $7.7 \mathrm{nnmol} / \mathrm{L}$, range 138-800 and cortisol in urine $<20 \mathrm{nnmol} / 24 \mathrm{~h}$, range $72.5-372$ ), hypogonadism (luteinizing hormone $1.1 \mathrm{IU} / \mathrm{L}$, range 1.7-8.6 and testosterone levels $<0.4 \mathrm{nnmol} / \mathrm{L}$, range 6.7-25.7), hypothyroidism (thyroid-stimulating hormone (TSH) $0.1 \mathrm{mIU} / \mathrm{L}$, range $0.4-4.0$ and thyroxin (T4) $45 \mathrm{nmol} / \mathrm{L}$, range 60-165) and growth hormone deficiency (insulin-like growth factor (IGF-1) 38.6 $\mathrm{ng} / \mathrm{mL}$, range 115-420). The patient underwent endoscopic transsphenoidal resection followed by total hypophysectomy because the diagnosis of pituitary apoplexy was assumed. It is important to note that the patient was admitted to our hospital 20 days from symptom onset and therefore did not undergo immediate surgery. Macroscopic examination of the sellar 


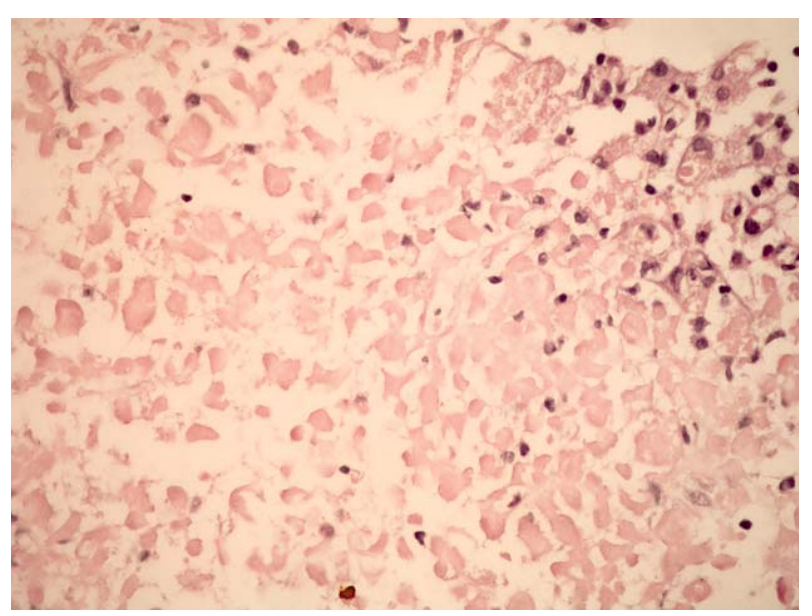

Fig. 2. Section of the inflamed pituitary gland showing necrotic pituitary tissue, marginally surrounded by siderophages and mononuclear inflammation cells (hematoxylin-eosin (HE), X400).

content showed a non-hemorrhagic grayish and soft tumorous mass without any traces of normal tissue, while histopathologic examination revealed necrotic pituitary tissue surrounded by siderophages and mononuclear inflammation cells (Fig. 2). There was no evidence for infiltrative, infective, or neoplastic processes. The diagnosis of $\mathrm{NH}$ was established, and replacement therapy with hydrocortisone $30 \mathrm{mg} /$ day, levothyroxine $75 \mathrm{mcg} /$ day, desmopressin $60 \mathrm{mcg} /$ day and testosterone undecanoate $1000 \mathrm{mg} / 12$ weeks was initiated. MRI performed four months after the surgery showed residual necrotic pituitary tissue measuring $12 \mathrm{~mm}$ within the left cavernous sinus (Fig. 1 E). This MRI finding remained unchanged 18 months later (Fig. 1 F). The patient remained well after the surgery.

\section{Discussion}

Necrotizing hypophysitis is an extremely rare clinical entity of unknown etiology, the diagnosis of which is currently established by combining endocrinologic, radiologic and histopathologic findings $\mathrm{s}^{2}$. Concomitant presence of hypopituitarism and diabetes insipidus in a patient with sellar mass should raise suspicion of hypophysitis. Typical radiologic findings include pituitary stalk thickening, pituitary enlargement and pronounced enhancement in the pituitary gland on dynamic contrast-enhanced MRI ${ }^{6}$. However, $\mathrm{NH}$ is the only type of hypophysitis presenting with lack of con- trast enhancement, which is attributable to the histopathologic finding of ischemic pituitary apoplexy, and is one of the reasons it is often unrecognized and misinterpreted as pituitary adenoma. However, it should be noted that pituitary adenomas do not cause diabetes insipidus ${ }^{3}$. Therefore, the triad of sudden-onset hypopituitarism, diabetes insipidus and radiologic findings of ischemic pituitary apoplexy should be a strong indicator of $\mathrm{NH}$.

All three previously published cases of $\mathrm{NH}$ presented acutely with sudden and severe headache, such as in our case. All of them had hypopituitarism, but diabetes insipidus was absent in one patient ${ }^{4}$. In all three cases, MRI showed isointense to hypointense sellar mass on T1-weighted sequences with thickened pituitary stalk and only rim contrast enhancement. Thus, we believe that the radiologic finding of ischemic pituitary apoplexy coupled with the presence of diabetes insipidus should be sufficient for diagnosis of $\mathrm{NH}$, although a larger study is necessary to confirm this hypothesis.

Our experience also suggests a possibility of conservative management of idiopathic hypophysitis. Although transsphenoidal surgery is a safe and effective method in the treatment of pituitary apoplexy ${ }^{7}$, conservative approach might be just as effective in patients experiencing milder symptoms without visual abnormalities ${ }^{8}$. Headache and diplopia in our patient resolved spontaneously, suggesting that conservative management might have been successful in this case. Moreover, residual necrotic pituitary tissue remained unchanged 18 months after the surgery and the patient experienced no symptoms. Hence, transsphenoidal surgery might not be mandatory in the treatment of $\mathrm{NH}$.

The cause of $\mathrm{NH}$ remains uncertain. However, since all common bacterial and viral infections were ruled out, it is plausible to state that it likely represents an autoimmune disease in which inflammation and limitation of blood flow cause ischemic necrosis via an unknown mechanism.

Here we report the first case of concomitant sterile meningitis caused by ischemic necrosis, which was previously associated only with rare instances of hemorrhagic pituitary apoplexy ${ }^{9}$. Since CSF infection was ruled out, we suggest that proinflammatory cytokines and debris released from necrotic pituitary gland could 
cause meningeal irritation and subsequently lead to sterile meningitis.

In summary, $\mathrm{NH}$ is an idiopathic disease that presents with sudden-onset hypopituitarism, neural compression, diabetes insipidus and radiologic features of ischemic pituitary apoplexy. Definitive diagnosis of $\mathrm{NH}$ could be made in patients with all these clinical elements, without the need for histopathologic confirmation. Conservative management could be considered in patients with $\mathrm{NH}$.

\section{References}

1. Caturegli P, Newschaffer C, Olivi A, Pomper MG, Burger PC, Rose NR. Autoimmune hypophysitis. Endocr Rev. 2005;26: 599-614. DOI: 10.1210/er.2004-0011

2. Gutenberg A, Larsen J, Lupi I, Rohde V, Caturegli P. A radiologic score to distinguish autoimmune hypophysitis from nonsecreting pituitary adenoma preoperatively. Am J Neuroradiol. 2009;30:1766-72. DOI: 10.3174/ajnr.A1714

3. Nakata Y, Sato N, Masumoto T, Mori H, Akai H, Nobusawa $\mathrm{H}$, et al. Parasellar T2 dark sign on MR imaging in patients with lymphocytic hypophysitis. Am J Neuroradiol. 2010;31: 1944-50. DOI: 10.3174/ajnr.A2201

4. Ahmed SR, Aiello DP, Page R, Hopper K, Towfighi J, Santen RJ. Necrotizing infundibulo-hypophysitis: a unique syndrome of diabetes insipidus and hypopituitarism. J Clin Endocrinol Metab. 1993;76:1499-504. DOI: 10.1210/jcem.76.6.8501157

5. Gutenberg A, Caturegli P, Metz I, Martinez R, Brück W, Rohde V. Necrotizing infundibulo-hypophysitis: an entity too rare to be true? Pituitary. 2012;15:202-8.

DOI: $10.1007 / \mathrm{s} 11102-011-0307-2$

6. Kamel N, Ilgin SD, Güllü S, Tonyukuk VC, Deda H. Lymphocytic hypophysitis and infundibuloneurohypophysitis; clinical and pathological evaluations. Endocr J. 1999;46:505-12.

7. Semple PL, Webb MK, de Villiers JC, Laws ER Jr. Pituitary apoplexy. Neurosurgery. 2005;56:65-72.

8. Ayuk J, McGregor EJ, Mitchell RD, Gittoes NJ. Acute management of pituitary apoplexy - surgery or conservative management? Clin Endocrinol (Oxf). 2004;61:747-52. DOI: 10.1111/j.1365-2265.2004.02162.x

9. Valente M, Marroni M, Stagni G, Floridi P, Perriello G, Santeusanio F. Acute sterile meningitis as a primary manifestation of pituitary apoplexy. J Endocrinol Invest. 2003;26:754-7.

Sažetak

\title{
ISHEMIJSKA APOPLEKSIJA HIPOFIZE, HIPOPITUITARIZAM I DIJABETES INSIPIDUS: TRIJADA SPECIFIČNA ZA NEKROTIZIRAJUĆI HIPOFIZITIS
}

\author{
M. Ćaćić, J. Marinković, I. Kruljac, B. Perić, V. Čerina, D. Stipić, L. Pažanin, H. I. Pećina i M. Vrkljan
}

Autori prikazuju rijedak slučaj nekrotizirajućeg hipofizitisa u 52-godišnjeg muškarca koji se inicijalno prezentirao apopleksijom hipofize i sterilnim meningitisom. Ovaj slučaj ukazuje na mogućnost da je dijagnozu nekrotizirajućeg hipofizitisa moguće postaviti i bez biopsije ako postoji patognomonična trijada ovoga sindroma: dijabetes insipidus, hipopituitarizam i radiološki znakovi ishemijske apopleksije hipofize. Dodatno, ovo je prvi opisani slučaj sterilnog meningitisa uzrokovanog ishemijskom apopleksijom hipofize.

Ključne riječi: Moždani udar; Dijabetes insipidus; Hipopituitarizam; Hipofiza, apopleksija; Meningitis 